\title{
The Increase of Region Own Source Revenue in Realizes the Prosperity of Papua Communities
}

\author{
Hengky Kayame, Marthen Arie, Abduk Razak, Farida Patittingi \\ Graduate School, Hasanuddin University, South Sulawesi, Indonesia
}

\begin{abstract}
The concept of autonomy in any country cannot be separated from financial issues. Self-finance or own revenue shows that the region (should) have self-revenue sources, and must be able to increase their own revenue. The research was a normative research with legal analysis method. The results shows that the strategy pursued by local governments to increase the Region Own Source Revenue is intensification strategy. The essence of this strategy is the way of local governments to seek other sources of local revenue that have not explored (still hidden). Another strategy is extensive strategy. This strategy is an effort to increase the Region Own Source Revenue through expansion and/or addition of object and subject of local revenue sources. Thus, the strategy of increasing own revenue in 5 (five) districts are aimed not only technical and legal approach as broaden the tax base or add a new tax type, but the government should divide the source of local revenue and not share the result of local revenue. Taxes and levies should fully be a tool to create the prosperity of peoples in their respective region.
\end{abstract}

Keywords: Autonomy, Local Government, Papua, Special Autonomy

\section{INTRODUCTION}

Post-reform the local autonomy has brought major changes in the system of local governance. Include the system and mechanism of local governance financial management. One of the essences of reform is the broad demands of autonomy to the regions. The essence is believed that decentralization or local autonomy is a means to accelerate the welfare of community. ${ }^{1}$ Therefore, the rule of law on local autonomy is enacted to provide greater autonomy to local governments to run the government and regional development.The local government is expected to design a strategy or model of an increase in region own source revenues, making it easier and more creative in exploring sources of financing, especially to meet the financing needs of government and local development through the principle of regional autonomy should always be oriented to the improvement of public welfare and to always pay attention to the interests and community' needs.

Critical issue that always arises when discussing the problem of local government is related to the issue of local financial. This issue is reasonable always arise because money is absolutely necessary in order to the implementation of government'duties and public service, particularly in the context of the public welfare. In financial management, local governments must be careful to avoid the occurrence of fraud and budgetary aberration due to malfeasance by state officials in the region. Therefore, financial management is absolutely necessary in order to secure and realize the overall prosperity of the people. The essence of local autonomy is independence or local freedom to self-regulate and organize the affairs and their interests based initiatives and aspirations of local communities. Thus, the region given autonomy on the basis of its own initiative to selfregulate the household by establish local regulations must not conflict with the State constitution and higher legislation and not contrary to the public- and national interests.

The concept of autonomy in any country cannot be separated from financial issues (no autonomy without funds). Success to organize and manage the household itself is a conditio qua non"self-finance". Selffinance or own revenue shows that the region (should) have self-revenue sources, and must be able to increase their own revenue. To conduct broad, real and responsible autonomy, the region must be able to prepare good human resources; financial factors were sufficient, adequate equipment as well as organizational factors and good organization and management. ${ }^{2}$ Region Own Source Revenue (hereinafter referred to as PAD) is a region revenue purely and the role is an indicator of the extent of autonomy has been implemented widely, tangible and accountable. Local revenue itself is very essential in its position for the operation of a local government. Even

\footnotetext{
${ }^{1}$ See the Consideration of the Act No. 23 of 2014 on Local Governance.

${ }^{2}$ Yosef Riwu Kaho,Prospek Otonomi Daerah di Negara Republik Indonesia, PT Radja Grafindo Persada, Jakarta, 2002, Page. 48.
} 
according A.W. Bradley and K.D. King in Mei Susanto said No government can exist without raising and spending money. ${ }^{3}$ Therefore, extracting and increasing the region own source revenue in maximum is expected and also able to improve its ability in organizing regional affairs. Frequently, the common problems faced by the local government is very limited authority in order to increase revenues (own revenue). For example, local taxes or levies. Even with the authority and limited taxes type, the region only has autonomy in determining the tax rate and a predetermined threshold. The other main problem is the weak management of own revenue. This weakness is a constraint and less support effective revenue management that may affect the realization of the achievement of revenue targets that have been implemented. These constraints that experienced by the local government in Papua province in the management of own revenue and can be caused, includes: (1) internal factors; human resources capacity, coordination, facility and infrastructure and a factor of region revenue potency. (2) External factors; lack of public awareness to pay taxes, the occurrence of natural factors that cannot be predicted.

Here the financial resources regarding Region Own Source Revenue in Papua province (Paniai, Timika, Jayapura, Jayapura City and Keerom). Based on result of observations found the problemsare, the first, the comparison between Own Revenue with subsidies ranging between 3\%: 97\%. The second, there are variation in Own Revenue contributions of Paniai district that only contributes between $0 \%-1.6 \%$, Timika29.3\%, Jayapura 6.2\%, Keerom $2.1 \%$, and Jayapura city $12.5 \%$. Further, Paniai district only has the ability to contribute inthe Own Revenue of $1.3 \%$ to the total revenue of Paniai district budget. This situation shows how strong the dominance of central financial in subsidies to Paniai district, which resulted in a very dependent of the region in its financial problems on subsidies from the central-or provincial government through special autonomy funds.Arrangement of such financial-relations puts autonomous regions (district and municipal) in a dependent positionto the higher levels of government. And consequently will lead to further utilization of region resources that is not optimal, and precisely the central government which often utilize this region resource and as result to reduce the self-reliant developmentand self-sustaining capacity of region.

The weakness of income planning and/or local revenue in all districts in Papua province may raise the possibility of under-financing or over-financing, which all affect the level of efficiency and effectiveness of the work units of local government. In general, the main problem facing the working unit that suffered under financing is the low capability of a work program to meet the needs and demands of the public. While, working unit which enjoys over-financing, its problem is low efficiency. In such situation, this lead many public services are run inefficiently and not in accordance with the demands of the public, while the existing funds in the local budget is public funds.

Based on the observations result of the author ${ }^{4}$ in the field, found the key issues highlighted in this study are: the internal problems of the organization; the problem of the external aspects of the organization, such as taxpayer still not fully aware of tax obligations; the problems of national scope, such as the needs of the region is not comparable with the existing local revenue sources, because the potential of each region is largely managed by the center; and finally the problem of local authority that very limited in order to increase revenues (own revenue). For example, local taxes or levies. Even with limited authority or tax type, the region only has autonomy in determining the tax rate and a predetermined threshold.

\section{METHOD OF RESEARCH}

This research was conducted in Papua Province, Indonesia in JayapuraCity, Jayapura, Keerom, Mimika and Paniai, with the consideration that since the passing of the special autonomy in Papua province, the fifth district and city has not a clear and systematic strategy and efforts about the increase of own revenue.The research was a normativeresearch with legal analysis method. ${ }^{5}$ All data obtained will be analyzed in complete, and then the data is systematized for analysis. The method used to analyze data is descriptive qualitative.

\section{RESULTS AND DISCUSSION}

\section{Local Government Strategy to Increase the Region Own Source Revenue}

Regional development is an integral part of national development, which aims to build the standard of living and the welfare of community. The standard of living and welfare of community are characterized by the Human Development Index, such as education, health, and economy. Therefore, the dynamics and acceleration in the development of region always brings new aspirations and demands continue to evolve in efforts to achieve a better quality of development. One is the emergence of the demands of the region in Papua province

\footnotetext{
${ }^{3}$ Mei Susanto, Hak Budget Parlemen di Indonesia, Sinar Grafika, Jakarta, 2013, Pages 7-8.

${ }^{4}$ Observation result of author di 5 (five) district namely Jayapura city, Jayapuran, Keerom, Mimika and Paniai of Papua Province in 2015-2016

${ }^{5}$ Peter Mahmud Marzuki, 2005,Penelitian Hukum, Kencana Prenada Media Group, Jakarta, Page. 96. 
by based on the wishes and expectations of the Papuans to play a larger role in achieving development and to realizing the Papua people (especially for Papua native) were advanced, independent, prosperous, and equitable.

In accordance with a decentralized system, the development of this nation started from the development of region or provinces. Each region explores and develops various potentials. The progress of development will determine the successful implementation of government, development, and community service in the region. The local autonomy makes local governments can regulate the series of government in the region to build welfare. Implementation of local autonomy aims to reduce the central governments' role in regulating each region in throughput of Indonesia.

Implementation of local autonomy occurs as a result adopts vertical power division. ${ }^{6}$ The principal reasons for vertical division of power are the presence of a number of affairs and are more efficient if implemented by the regions. This vertical model of power-division requires local governments to manage and develop the region. It is certainly not independent of the financing to be incurred by local governments. Regarding this needed revenue in the implementation of local autonomy. One source of income is Region Own Source Revenue. The potential of a region must continue to be encouraged so that the results can be maximized.

Own revenue indicates the ability of a region to finance the exercise of the powers/authority owned and is one of the supporting factors that determine the success of the implementation of local autonomy. ${ }^{7}$ Sources of Own Revenue obtained can be used to finance the implementation of the Local Government affairs. Local spending used to fund the implementation of government affairs under the authority of the provincial or district/municipal, which consists of obligatory, selective matters, and matters were handled in a particular field. Expenditure for obligatory affairs shall be prioritized to protect and improve the quality of life of people in order to meet the obligations of the region through improving basic services, education, health, social services and public facilities as well as developing a viable social security system.

Based on the analysis, and considering demand of regions in Papua province, it must be appreciated by the Central Government for more wise and prudent, especially in encouraging enthusiasm that emerging in the region, to be able to optimize in encouraging the process of autonomy and concerned regional empowerment. For, if lacking in appreciation, not impossible will have an impact on the process of disintegration. The demand occurs in several areas in Papua that ongoing develop their region (sustainable development) in order to be better and be able to realize a society prosper. ${ }^{8}$ Papua province as special autonomy to date has been a lot of carrying out development, both human development and physical development of socio-economic infrastructure. Development is a tool that aims to build the welfare of community.

All regions in Indonesia are required to be more independent, both in running their government and fund their regional. The implications of the autonomous regions are each region should be able to manage and develop their potential to uphold the success of local autonomy. Potential developed includes human resources, natural resources management, the ability to manage local finances, social and cultural conditions, and management capabilities. Overview of local financial independence can be seen by the amount of the ability of financial resources to finance the public service to a particular area. ${ }^{9}$

Other own revenue sources are region-owned enterprise, which is an enterprise owned by the local government in which the formation, incorporation, release ownership, or its dissolution are stipulated by local regulations which are based on legislation. Results of legitimate local governance as a local revenue from profit/net income of the region enterprise for regional budget paid to both local treasury both regional enterprise whose capital is partly composed of separated regional wealth. The regional enterprises like Drinking Water Company, Regional Development Bank, hotel, theatre, printing, city bus and the market are the kinds of enterprises that have great potential as sources of revenue. Other region revenue that more strategic is other income as Own revenue include the sale of fixed assets and current accounts. Success in implementing local autonomy is of course inseparable from the role of Own revenue as the largest source of local revenue.

In principle, the greater of contribution of Own revenue to the regional revenue will show less dependence on the region to the central. With the contribution increases are expected the region to increasingly

\footnotetext{
${ }^{6}$ The reason of power division vertically are (a) the ability of government and local apparatus are limited, (b) the territorial of State is very broad, about 3000 large and small Island, (c) the government do not know any kind of interest and community' needs, and (d) only local community know the needs, interest and problems faced by them and more know how the best way to meet their needs, such as the prosperity of community and goof public service.

${ }^{7}$ Bachrul Amiq,Aspek Hukum Pengawasan Pengelolaan Keuangan Daerah: Dalam Perspektif Penyelenggara Pemerintahan yang Bersih. LaksBang PRESSindo, Yogyakarta, 2010, Page. 86.

${ }^{8}$ Karianga, H. (2016). New Paradigm for Local Financial Management: A Review of Local Budgeting System.Hasanuddin Law Review, 2(3), 398-408.

${ }^{9}$ Purnomo, H.Era Baru Kebijakan Fiskal. Jakarta: PT Kompas Media Nusantara, 2009, Page. 156. 
able to finance its spending. Overview of local financial independence can be seen by the amount of the ability of financial resources to finance the public service to a particular area. ${ }^{10}$

One strategy that can be done is by using Intensification Strategy. ${ }^{11}$ The essence of this strategy is the way local governments to seek other sources of income that have not explored (still hidden) and increase the coverage ratio ${ }^{12}$. Intensification focused on improving the quality of taxes and levies, simplification of bureaucracy, increase administrative order, enforcement of sanctions, increased communication and information to the public as well as the reform of local taxation system.

Regional Revenue Office of Jayapura city, Jayapura and Mimika has sought to increase local income by intensification of hotel taxes. ${ }^{13}$ In order not to decline in income, the Regional Revenue Office optimize revenue from the hotel tax, since the tax hotel sector is a major contributor to revenue, in addition to the tax sector can give the potential of the new economy, such as restaurant, entertainment and street lighting, taxes, property tax, BPHTB and others. Besides, the fifth region is also pursuing a strategy of Own revenue through intensification especially for particular permit levies and business.

\section{Constraints to Increase the Region or Municipal Own Source Revenue in Papua Province}

Ideally, the Own revenue is one of the sources of region revenue comes from its own region and used to build and finance the system of governance in the region for achieves the welfare of the community. Regional tax is one component in the local revenues and the greatest contribution in earning Own revenue. Income as region revenue becomes the most important thing in building a welfare society. Human development, such as the development of health, education, economy and infrastructure in the region is the real indicators to measure the extent of the benefits of Own revenue to the welfare of the community. Therefore, the increase in revenue should really get serious attention from the government of Jayapura city, Jayapura, Keerom Timika and Paniai to be optimized and developed the whole potential to be exploited for the benefit of society in their respective regions.

Revenue management in Jayapura city, Jayapura, Keerom, Mimika and Paniai contains measurable estimates principle, rational, and has basic legal certainty, by attention to the principles of revenue management as follows; management of revenue is based on the public interest, transparent and rational, performance-based management approach, professionally managed and low cost. Local revenue policies directed at efforts to seek out and utilize the full potential of the region to anticipate the region spending that continues to rise each year.

Discussion about the constraints faced by local governments at the district/municipal of Papua province in increase the Region Own Source Revenue, the authors emphasize the discussions that are legal-formal, by law or regulation. Various normative constraints that occur in some local government in Papua province in particular and other provinces in Indonesia in general area process for delegating power occur distortion between laws and official regulations and its implementation. In addition, the central government considers the local government does not want to implement local autonomy, otherwise the local government regard that central or provincial government does not expressly and fully delegate authority, to the region can develop independently in accordance with the nature of autonomy. With the implementation approach will better understand the factors that may affect the implementation of decentralization and autonomy.

Thus, the implementation approach can describe the interaction between these external factors with formal discretion regarding local autonomy. It was time to be determined and achieved a consensus based on the decentralization, as a form that suits with our autonomy (not based on statutory provisions or compliance). Based on the experience of the implementation of local governance (decentralization authority) the achieving of the ethics of autonomy implementation ${ }^{14}$ of all components the central government, provincial and regency/municipal. Nakamura and Smallwood in the Politics of Policy Implementation (1980) as quoted by Warsito Litom identified 2 (two) approaches in policy implementation that are the compliance approach and the political approach. In compliance approach, implementation is regarded as a technical process, routine, and $a$

\footnotetext{
${ }^{10}$ Erly, Suandy, Perpajakan Edisi 2. Salemba Empat. Jakarta, 2006, Page. 138.

${ }^{11}$ Intensification is the increase of Region Own Source Revenue through optimization process of local sources and recently it has been managed by the local government.

${ }^{12}$ Coverage ratio is amount the tax object has been collected than the tax object that should be charged by $\operatorname{tax}$.

${ }^{13}$ Marihot P. Siahaan. 2005. Pajak Daerah dan Retribusi Daerah. Jakarta: PT. Raja Grafindo Persada, 2005. Page. 245.

${ }^{14}$ This term is raised by the concept as described by Tjokrowinoto in his paper titled: Pembangunan Politik di Indonesia Political Progress, Involusi Politik, atau Political Decay. In this paper explains the concept of The Ethic of Pluralismthat need to be developed so the group with different opinion can be consistent with the spirit to respect one another. So, the culture of politics growth as developed in the scheme of Pancasila democracy.
}

DOI: 10.9790/0837-2204044552 $\quad$ www.iosrjournals.org $\quad 48 \mid$ Page


political. Thus, the implementation of discretion is relying on the Classical Hierarchical Model ${ }^{15}$ where there is a difference or separation between policy-making with policy implementation. On the political approach, implementation is an integral part and are in the process of policy-making. Here there was the process of filtering and smoothing, reformulate, or sometimes discretion is not used or even canceled. ${ }^{16}$

Local taxes and levies are manifestations of public participation in local governance. It is a source of revenue and very crucial for financing local governance and development. The problem faced by the region in general in terms of extracting the sources of local taxes and levies are not contributing significantly to the throughput of local revenue.

In general, efforts should be made by the local government in order to increase local revenues by optimizing the intensification of local tax collection and levies, can be done in the following ways:

1. Expanding the revenue base for taxes and levies in Jayapura city, Mimika, Jayapura, Keerom and Paniai. This effort is intended to expand the revenue base that can be levied by the regions. Strategy to expand the tax base if seen from the economic aspect is very potential, by identify new taxpayers/ potential and the number of taxpayers, repair object database, and improve assessment, calculating the capacity of revenue for each type of levies.

2. Strengthening the process of taxes and levies collecting to strengthen the collection process, by increasing the capacity and capability of human resources. This is very important because it will encourage the strategies and measures that have been defined by local governments.

3. Improving the supervision of taxes and levies in the district and the municipal. This can be improved by conducting regular inspection every 6 months or 1 year conducted regularly by the Region Revenue Office, improving the supervision process, and sanctions for hotel tax defaulters who are unable to pay as defined rules.

4. Increasing administrative efficiency and reduce the cost of collections. These efforts made among others; improve tax administration procedures through the simplification of tax administration, improve the efficiency of collection of each type of collection. Each collection or payment process is carried out when the hotel to pay taxes to the Region Revenue Office and the party of Region Revenue Office able to providing the process of payment are fast and efficient.

While the inhibiting factors to improve the local taxes, such as the hotel tax is (i) many problems that occur in several district/cities in Papua province today, especially in Jayapura city and Jayapura, Keerom, Mimika and Paniai for exploring and an increase in Own revenue, in particular taxes and levies. To anticipate the process of decentralization and local autonomy seems to taxation and levies still cannot be relied upon by the region as a source of decentralization funds. This situation is shown in a study conducted by the LPEM-UIin collaboration with the Clean Urban Project, RTI that many problems occurred in the region is related to the exploring and an increase in Own revenue, mainly this is due to:

1. Relatively low tax base in this region. Based on Act No. 23 of 2014 that district/municipal enables to define new types of taxes and levies. However, looking at criteria for new tax are very strict, particularly local tax criteria it not overlap with the central and provincial taxes, it estimated that a region has a relatively low tax base and limited, and varied between regions. The low tax base and levies for Jayapura city, Jayapura, Keerom, Timika and Paniai means to lessen the ability of local innovation and creativity to manage the local finance in facing the financial difficulties.

2. Some reception sectors such as local taxes and levies are relatively small role in the total revenue, especially in Mimika, Keerom and Paniai. Most of the local revenue still comes from grants (Common Allocation Fund and Special Allocation Fund from the central government). In terms of tax collection, the amount of aid and subsidies reduce the effort in collecting tax intensification to increase its own revenue, and rely more on the ability to negotiate with the central government to get additional aid.

3. The administrative capabilities of taxation and levies that is still low. This implies that tax collections tend to be burdened by a large collection costs. For example, parking levy, the cost of collection and operational costs are larger or average reached $80 \%$, while that paid to the local government about $20 \%$ of the results of collection for parking. Own revenue is still classified as having a low level of revenue. One reason is applied to the target system in local tax collecting by the Region Revenue Office. As a result, some region tends to meet these targets, though in terms of economic growth the tax revenues and levies may exceed the target.

4. Supervision ability for hotel tax is weak. This resulted in leakages are very significant for the region. During time, the role of local taxes to finance local expenditure needs are very small and varied. The role of local tax in financing are very low and vary as result of various differences in population and geographic conditions

\footnotetext{
${ }^{15}$ According to the author, this term shows that decentralization in Indonesia is not growth from bottom but it determined by the central government, that is from central to provincial and then to the local government.

${ }^{16}$ Warsito Litom, Peranan dan Strategi Peningkatan Pendapatan Asli daerah Dalam Pelaksanaan Otonomi Daerah,
} 
(impact on the relatively-expensive cost), and the ability of people, resulting in the cost of providing services to the public is very varied. ${ }^{17}$

\section{Diagram 1. Local Tax Intensification}

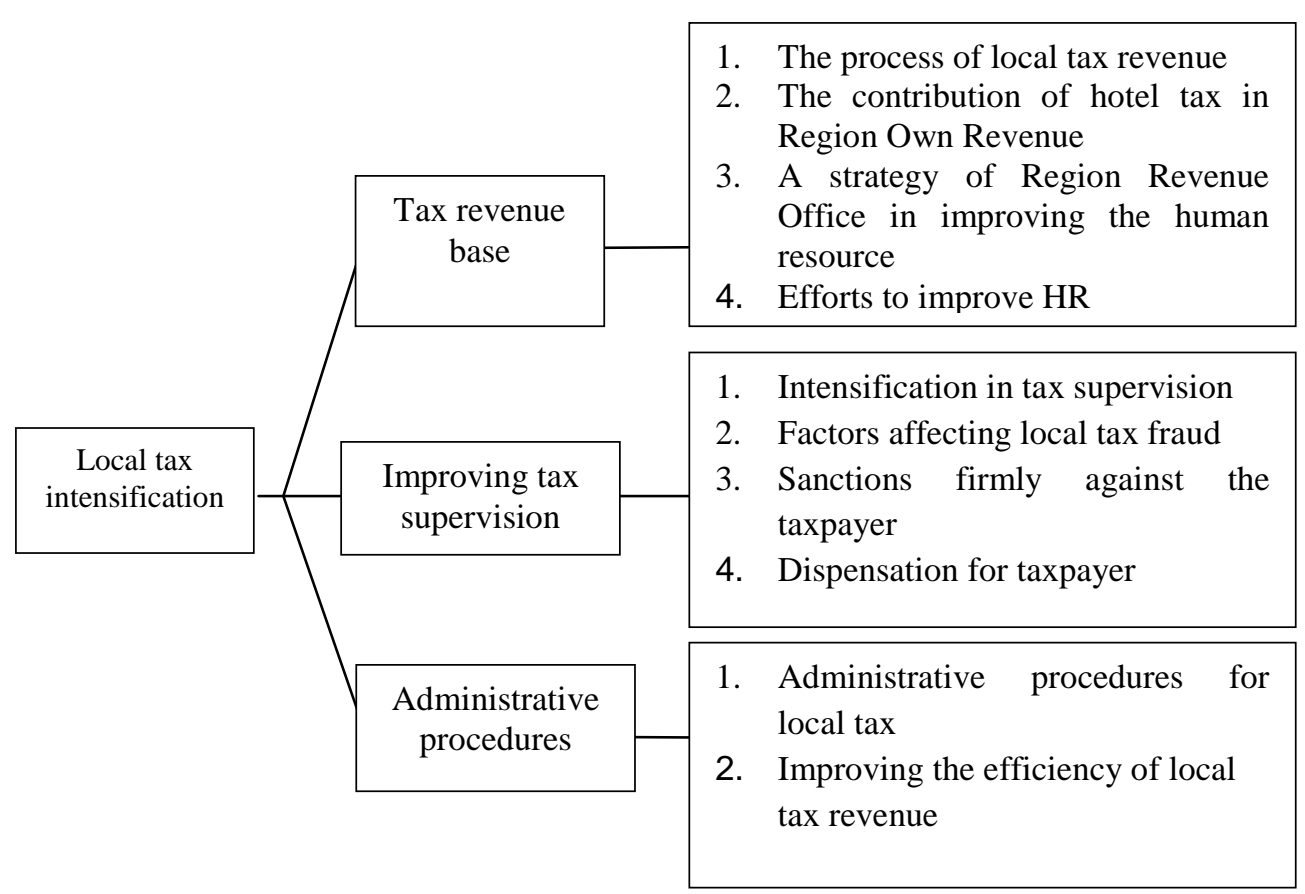

Source: primary data as compiled from various sources, in 2016.

Insignificant role of local taxes in the local budget cannot be separated from the system of tax collection in nearly all district and cities in Indonesia, which still gives full authority to the central government to collect potential taxes (it certainly based on certain considerations), such as: income tax, value-added tax and toll. Imbalances in the control of the sources of tax revenue it provides clues that the financial balance between central and local governments in Indonesia in terms of revenue assignment is still too centralized.

For example, several constraints faced by local governments in Paniai, in the period up to now are:

\section{a. Ignorance taxpayers on tax regulations}

This condition is the inhibiting factor to implement the intensification and expansion programs. In terms of the understanding about legal rules governing the rights and duties is the main capital to comply with applicable regulations. Person understanding about the rule of law is one of the requirements of effective compliance of citizens against the law. To realize this condition in Paniai, the Region Revenue Office often conducting socialization of taxation so that citizens know the tax laws and regulations. In addition to socialization, the Region Revenue Office of Paniai also provides and appeals to the public (taxpayers).

$b$. The lack of taxpayers' participation to support tax expansion and intensification

The success level of tax expansion and intensification is not only of the officers/ officials. The active role or participation of the public, especially taxpayers also support the successful implementation of the tax expansion and intensification by local governments. However, not all taxpayers concerned and willing to cooperate with the local authorities. The observation of the authors also shows most taxpayer think, when met with tax officials is the fear of paying taxes. Whereas the tax officers is not come to the taxpayer to directly impose sanctions but to request information or data are needed so that in this process the tax officer/ authorities can provide good service and friendly to the taxpayer. Both constraints according to the author's observation is

\footnotetext{
${ }^{17}$ Local autonomy as the implementation of decentralization governance system is not separate from various weakness, includes (i) the local government that regulate its region by establish local regulation that conflict with higher regulation, (ii) the supervision of central government is weak, (iii) the problem is vulnerable occur in the region, (iv) regulation from central government is often not accordance to the condition of certain region, and (v) often occur difference in progress between autonomy region.

DOI: 10.9790/0837-2204044552 $\quad$ www.iosrjournals.org $\quad 50 \mid$ Page
}


also experienced by peoples in Keerom, while in Mimika, Jayapura and Jayapura city this have begin to decrease.

\section{c. Limitations of data for the implementation of tax expansion and intensification}

This is due to limited data held by the Region Revenue Office in each research areas. One for the implementation of the tax expansion and intensification still influenced by these constraints is the lack of an active role of the taxpayer. This becomes a real constraint because the data needed to perform the tax expansion and intensification comes from the taxpayer. If the taxpayer does not want to play an active role to help the tax authorities to provide data/information needed expansion and intensification then implementation is not going to be effective. Besides, the limited number of tax officials was not match to the number of taxpayers, resulting in ineffective implementation of tax intensification in the field.

Insignificant role of Own revenue in local budgets cannot be separated from the "tax assignment system" in Indonesia, which still gives full authority to the central government to collect potential taxes (which must be based on certain considerations), such as income tax, value-added tax and toll. The fact so far has shown that the distribution of authority between the central and local tax collection in Papua province almost all districts and cities so overlap, that is the amount of tax revenue collected by the region amounted to only $0.78 \%$ $-19.30 \%$ of total tax revenue (overlapping central- and local taxes in the control of the sources of tax revenue it provides clues that the financial balance between central and local governments in Indonesia in terms of revenue assignment is still too "centralized".

Empowerment and exploring the source of local revenue has several objectives. Roy Bahl and Linn ${ }^{18}$ mention 4 (four) objectives in the improvement of the regional financial resources. First, in order to mobilize resources, variations in creating a form of local government revenues, both in terms of basic charges and tariffs, will bear a greater than when fixed on one kind of revenue only. In this case the local authorities have a greater opportunity to make these variations, because every region has the potential and different characteristics.

The second is economic efficiency. Selection of resources allocation in the region will affect the efficiency of resource use. Inappropriate determination of tax system allow for the allocation of resources be inefficient. In this case, the region to know more about the condition and potential of their region, so the reform of revenue system through tax, for example, will lead to the conditions of resource allocation is more efficient.

The third is equity. Equity can be interpreted as a balance between the sacrifices given by the benefits received by the payer. In this case, the region that has been autonomy has greater authority in the provision of public goods and services to its peoples. Thus, the dimension of equity in terms of this approach gives a clue to the region to have the authority in determine the source of revenue or income.

The fourth is administrative feasibility. The level of administrative capacity of each region is different. In this context, the improvement in the aspect of revenue aimed to improve administrative feasibility that will directly implicate to the revenue effort of the concerned region.

In empowerment and exploring source of revenue is not infrequently encountered various constraint. The first in the form of legislation that do not support those efforts; or when legislation is made with the purpose to make corrections or improvement, but on the other hand there are laws and regulations that are not in the same breath. Likewise, efforts to correct local revenue sources often conflict with the political interests of certain parties, in this case for example in conflict with the political interests of the central government.

In this condition the improving policy of local financial resources often exist only on paper, but not in accordance with the implementation on the ground. The firstconstraint is the legal and political constraints. The secondappear in the aspect of the administrative structure. The condition of administrative structure, including the weak condition of the government bureaucracy and rigidity, both within the capabilities of human resources, systems and procedures, as well as institutions, can lead to less successful reform policies for local revenue. The third related to local economic conditions. The improving policy of financial resources without supported by the ability the regional economy is good, will not yield substantial revenues. Bahl et al ${ }^{19}$ refers to this constraint as economic constraints. For examples, if conduct the diversification of tax object, however, if a region does not have a lot of potential taxes, then this diversification policy will not work in the region. Finally, the constraint of technological, culture and institutions. In this case, the ability of technology including methods needed to support the reform of revenue, community cultural conditions that are less in response to government policy, and institutional bureaucracy that is also less accommodating, can cause failure of the improving policy of local revenue.

\footnotetext{
${ }^{18}$ Roy Bahl.W \& Johannes F. Linn, Urban Public Finance in Developing Countries, A World Bank Book, Oxford University Press, New York, 1998, Pages 391-396.

${ }^{19}$ Ibid.p 399 
Related to the constraints, 2 (two) tips for the success of the reforms that is compliance incentives and administrative incentives. The first, emphasizing the mobilization of revenue efforts through incentives or disincentives to the payers, while the second is incentives for administrators and local government itself.

Incentives for payers (compliance incentives) can be carried out through 4 (four) ways. First, benefits of paying; taxpayers get the most benefits from the public goods provided from the revenue source. Second, penalties for income subject who'snot to pay. Third, the imposition of higher costs for late taxpayers if compared to the compliance costs. Fourth, conduct structural reform. The latest tip is an improvement in the system of self-income. This is very important because to yield public confidence in the government, then the system adopted should be well understood by the public.

Administrative incentives, can also be done through 4 (four) ways. First, the provision of pecuniary incentives to the collector or performance collectors. Second, the provision of power and advancement for performance employees. Third, expenditure incentives, if the local government is able to collect revenue, it means the larger of governments' ability to carry out expenditure. Especially, this is influential in a democratic state that is relatively democratic and more frequent change in its government, so that the planned programs for development are short-term. Fourthis inter-governmental aid. This way is an alternative if self-income is not sufficient to finance the development.

\section{CONCLUSION}

The strategy pursued by local governments in Jayapura city, Jayapura, Keerom, Mimika and Paniai of Papua Province to increase the Region Own Source Revenue is intensification strategy. The essence of this strategy is the way of local governments to seek other sources of local revenue that have not explored (still hidden). Another strategy is extensive strategy. This strategy is an effort to increase the Region Own Source Revenue through expansion and/or addition of object and subject of local revenue sources. Furthermore, another strategy is to strengthen the policies and regulations by make local regulations are firmly and clearly regarding taxpayer and levy, tax object and levies and tax rates as well as the collection procedures are clear and transparent. Several constraints faced by the local governments to increase the Own Revenue is ignorance of taxpayers on tax laws and regulation; the lack of taxpayers' participation to support the tax intensification and extensive; the limitations of the data for the implementation of the tax intensification and extensive; the relatively low base of taxes and levies; and the ability of local tax officials that are still low.

The increasing of Municipal/Region Own Source Revenue in Papua province should be based on the factors of special autonomy, and should be fundamental in achieving the objectives of regional autonomy to accelerate the prosperity of people. Thus, the strategy of increasing own revenue in 5 (five) districts are aimed not only technical and legal approach as broaden the tax base or add a new tax type, but the government should divide the source of local revenue and not share the result of local revenue. Taxes and levies should fully be a tool to create the prosperity of peoples in their respective region.

\section{REFERENCES}

[1] Bachrul Amiq,Aspek Hukum Pengawasan Pengelolaan Keuangan Daerah: Dalam Perspektif Penyelenggara Pemerintahan yang Bersih. LaksBang PRESSindo, Yogyakarta, 2010.

[2] Erly, Suandy, Perpajakan Edisi 2. Salemba Empat. Jakarta, 2006.

[3] Karianga, H. (2016). New Paradigm for Local Financial Management: A Review of Local Budgeting System.Hasanuddin Law Review, 2(3), 398-408. doi:http://dx.doi.org/10.20956/halrev.v2i3.700

[4] Marihot P. Siahaan. Pajak Daerah dan Retribusi Daerah. Jakarta: PT. Raja Grafindo Persada, 2005.

[5] Mei Susanto, Hak Budget Parlemen di Indonesia, Sinar Grafika, Jakarta, 2013,

[6] Peter Mahmud Marzuki, Penelitian Hukum, Kencana Prenada Media Group, Jakarta, 2005.

[7] Purnomo, H. Era Baru Kebijakan Fiskal. Jakarta: PT Kompas Media Nusantara, 2009.

[8] Roy Bahl.W \& Johannes F. Linn, Urban Public Finance in Developing Countries, A World Bank Book, Oxford University Press, New York, 1998.

[9] Yosef Riwu Kaho, Prospek Otonomi Daerah di Negara Republik Indonesia, PT Radja Grafindo Persada, Jakarta, 2002. 